\title{
Viral and bacterial dynamics in Arctic sea ice during the spring algal bloom near Resolute, N.W.T., Canada
}

\author{
Roxane Maranger ${ }^{1}$, David F. Bird ${ }^{1}$, S. Kim Juniper ${ }^{1,2}$ \\ ${ }^{1}$ Département des Sciences Biologiques, Université du Québec à Montréal, CP 8888, Succ. 'A', Montréal, Québec, \\ Canada $\mathrm{H} 3 \mathrm{C} 3 \mathrm{~PB}$ \\ ${ }^{2}$ Centre de Recherche en Géochimique Isotopique et en Géochronologie (GÉOTOP), Université du Québec à Montréal, \\ CP 8888, Succ. 'A', Montréal, Québec, Canada, H3C 3 P8
}

\begin{abstract}
High virus counts were found in Arctic sea ice samples taken during the spring ice algal bloom near Resolute, Northwest Territories, Canada. Viral abundances in the sea ice ranged from $3.7 \times$ $10^{11}$ viruses $\mathrm{m}^{-2}$ (or $9.0 \times 10^{6} \mathrm{ml}^{-1}$ ) to $4.9 \times 10^{12} \mathrm{~m}^{-2}\left(1.3 \times 10^{8} \mathrm{ml}^{-1}\right.$ ) which is 10 - to 100 -fold greater than the concentration of viruses in the underlying water column $\left(1.1 \times 10^{6} \mathrm{ml}^{-1}\right)$. This increase in viral abundance corresponds with the 10- to 100-fold increase in bacterial abundance in sea ice as compared with the water column. Bacterial abundances ranged from $6.1 \times 10^{9}$ bacteria $\mathrm{m}^{-2}\left(1.5 \times 10^{5} \mathrm{ml}^{-1}\right)$ to $4.2 \times 10^{11}$ $\mathrm{m}^{-2}\left(1.0 \times 10^{7} \mathrm{ml}^{-1}\right)$ from early to late spring respectively. The virus-to-bacteria ratios (VBR) were among the highest reported in natural samples. The greatest viral abundances occurred in the 0.5 to $1.5 \mathrm{~cm}$ layer of the ice profile, where the bacteria were most active. The VBR generally decreased during the spring although viruses were increasing in abundance. The disequilibrium between phage and bacterial growth and abundance maxima during the spring bloom is suggested to be due to (1) a change in the makeup of the bacterial community, such that phage-resistant bacteria proliferated later in the spring, or (2) an increase in viral lytic activity with higher bacterial cell-specific growth rates; both viral lytic activity and bacterial growth rates declined later in the spring as the bacterial population reached its peak.
\end{abstract}

KEY WORDS: Viruses - Bacteria $\cdot$ Bacteriophage $\cdot$ Sea ice $\cdot$ Spring bloom $\cdot$ Arctic

\section{INTRODUCTION}

Recent discoveries have shown viruses to be extremely abundant in aquatic ecosystems. Direct counts using electron microscopy have yielded abundances of $10^{3}$ to $10^{8}$ viruses $\mathrm{ml}^{-1}$ in marine and fresh waters (Bergh et al. 1989, Klut \& Stockner 1990, Proctor \& Fuhrman 1990). Such high viral counts have led to suggestions that viruses may be partly responsible for the control of bacterial and algal populations through cell lysis induced by viral infection. Supporting evidence is based on the high proliferation rates of viruses in marine water samples (Bratbak et al. 1990), the direct observation of marine bacteria containing mature phage particles (Proctor \& Fuhrman 1990), and the maintenance of large populations of viruses despite the rapid disintegration of free viruses (Heldal \& Bratbak 1991)

Viruses are suggested to be active members of the microbial food web. By controlling bacterial productivity through cell lysis, viruses may eliminate a fraction of bacteria from the predatory food chain (Bratbak et al. 1990). Phage may influence carbon flow and the release of dissolved organic matter (DOM) in microbial communities (Proctor \& Fuhrman 1991, Bratbak et al. 1992, Fuhrman 1992). Lysis products consisting of progeny phage and fragments of burst bacterial cells, all of which are small enough (20 to $200 \mathrm{~nm}$ ) to be considered dissolved (Ackerman \& Dubow 1987a), may contribute significantly to the DOM pool (Fuhrman 1992). In addition to being involved in the control of bacterial and algal populations and in nutrient and car- 
bon cycling, viruses may play an important role in the transfer of genetic material between organisms via transduction (Paul et al. 1991).

Annual sea ice in the Arctic and Antarctic develops important and dynamic microbial communities (Grossi et al. 1984, Kottmeier et al. 1987, Smith et al. 1989). This algal community is the primary food source for many grazers, including amphipods and copepods (Horner 1989). It is also known that during the vernal bloom of ice algae, heterotrophic bacterial abundances increase exponentially within the ice as bacteria assimilate locally produced DOM (Smith \& Clement 1990). The ability of viruses to exploit this productivity has never been investigated.

The objectives of this study were to determine whether viruses are present in sea ice and to document the relationship between viral and bacterial abundances and bacterial production in Arctic sea ice during the spring bioom of ice algae. A profile of viral and bacterial distribution within the ice was also evaluated, and compared with water samples taken at the icewater interface and at various depths in the underlying water column.

\section{MATERIALS AND METHODS}

Sampling site. Samples were collected south of Resolute, Northwest Territories, which is located on Cornwallis Island in the Canadian Arctic $\left(74^{\circ} 40^{\prime} \mathrm{N}\right.$, $\left.94^{\circ} 54^{\prime} \mathrm{W}\right)$. Ice samples were collected from sites with relatively thin snow cover $(<10 \mathrm{~cm}$ thick), which had previously been identified as potentially rich in ice algae (Smith et al. 1989).

Sampling methods. Ice core samples for the temporal study were taken using an auger driven SIPRE corer $(7.62 \mathrm{~cm}$ in diameter). Triplicate ice core samples were taken every 4 d between April 22 and May 22, 1992. The bottom $4 \mathrm{~cm}$ of the ice core was cut off and all 3 cores were melted in prefiltered $(0.2 \mu \mathrm{m})$ surface sea water, with an approximate dilution factor of 3 . The original project was designed to look at bacterial dynamics only, hence the water used for the dilution of the ice was prefiltered at $0.2 \mu \mathrm{m}$. The temperature was monitored during the melting process and was not allowed to exceed $5^{\circ} \mathrm{C}$. Once melting was complete, which took approximately $90 \mathrm{~min}$, samples were pooled and placed in a bath at ambient seawater temperature $\left(\mathrm{ca}-1.8^{\circ} \mathrm{C}\right)$. Ice water samples for thymidine incorporation were taken directly from this pool.

For the ice profile, core samples were collected with a remote-controlled sampling arm $(10 \mathrm{~cm}$ in diameter). A heated metal collar is inserted into the ice from the underside of the ice. Once the collar has penetrated approximatgely $8 \mathrm{~cm}$ into the ice, a heated metal wire cuts through the ice enabling the arm to remove the core. An ice sample is obtained with minimal perturbation of the ice-water interface. A small video camera located on the end of the arm enables the operator to remotely guide the insertion of the collar. Water column samples were taken using a 51 Niskin bottle, and the interface water sample was taken using the mechanical arm. Samples for viral and bacterial enumeration were fixed with prefiltered $(0.2 \mu \mathrm{m})$ borax buffered formaldehyde ( $2 \%$ final concentration).

Enumeration of bacteria and viruses. Bacteria were stained directly with DAPI and filtered onto black $0.2 \mu \mathrm{m}$ pore-size polycarbonate filters (Porter \& Feig 1980). Samples were enumerated by epifluorescence microscopy at a final magnification of $1250 \times$.

Viruses were pelleted directly onto 400 mesh Formvar coated $\mathrm{Cu}$ grids using an EM-90 rotor in a Beckman airfuge (Hammond et al. 1981). After centrifugation at $100000 \times g$ for $30 \mathrm{~min}$, grids were floated on prefiltered $(0.02 \mu \mathrm{m})$ distilled water droplets to remove salts (Suttle 1993). Grids were air dried, stained with $2 \%$ uranyl acetate for 5 min and counted directly at high magnification $(90000 \times)$ using a Phillips EM300 transmission electron microscope. To evaluate the virus recovery efficiency of the EM-90 rotor, a known concentration of T5 phage (an extensively studied lytic bacteriophage of Escherichia coli) was pelleted onto formvar coated grids. These T5 samples were manipulated and enumerated using the same method as for the ice-water samples. Recovery efficiency was estimated to be $96 \%( \pm 19 \%)$.

In order to achieve an accurate estimation of viral abundance, 50 fields were observed per grid. By counting the viruses in 5 fields in 10 grid squares, we were able to observe a greater area of the grid. Enumeration was done at high magnification $(90000 \times)$ to ensure that the particles we enumerated were indeed virus-like. Viruses were identified on the basis of the size of the particle (20 to $120 \mathrm{~nm}$ in capsid diameter), on icosahedral head capsid morphology, and on staining characteristics. Depending on the number and configuration of capsomeres, capsids may appear to be more round in shape than hexagonal. Viruses were categorized in the following size classes: $<50,50-70$, $70-100$, and $>100 \mathrm{~nm}$. Non-filtered samples of the surface sea water used in the dilution of ice samples were enumerated for each collection date. Ice virus abundance was corrected for the presence of viruses in the $0.2 \mu \mathrm{m}$ filtered sea water used for melting the cores, by using the abundances in non-filtered surface water samples. It is possible that some of the viruses in the surface sea water adsorbed to the $0.2 \mu \mathrm{m}$ filter when this water was prefiltered. Because we assumed that $100 \%$ of the viruses passed through the filter, our ice viral counts may be slight underestimates. 
Bacterial production. Production was measured using ${ }^{3} \mathrm{H}$-thymidine following the method of Fuhrman \& Azam (1982) as modified for ice samples by Smith \& Clement (1990). Five replicates and 1 trichloroacetic acid (TCA)-killed control (5\% final concentration) were incubated for $6 \mathrm{~h}$ at ambient sea water temperature $\left(\mathrm{ca}-1.8^{\circ} \mathrm{C}\right.$ ). Approximately $5.0 \mathrm{nmol} \mathrm{l}^{-1}$ of labelled thymidine with a specific activity of $85 \mathrm{Ci}$ $\mathrm{mmol}^{-1}$ was added to $20 \mathrm{ml}$ samples. Incubation was terminated with the addition of TCA to a final concentration of $5 \%$. After a 30 min wait to permit nucleic acid precipitation, samples were filtered onto $0.2 \mu \mathrm{m}$ pore cellulose nitrate filters, washed twice with $5 \%$ TCA, and assayed for radioactivity.

Chlorophyll a. Full description of how chlorophyll samples were collected and analysed is available in Levasseur et al. (in press).

\section{RESULTS}

Viruses were present and very abundant in these Arctic sea ice samples (Fig. 1). The number of viruses found in the lower $4 \mathrm{~cm}$ of the ice ranged from $3.7 \times$ $10^{11} \mathrm{~m}^{-2}\left(9.0 \times 10^{6} \mathrm{ml}^{-1}\right)$ to $4.9 \times 10^{12} \mathrm{~m}^{-2}\left(1.5 \times 10^{8}\right.$ $\mathrm{ml}^{-1}$ ) (Fig. 1). These abundances are 10- to 100 -fold greater than the virus counts made in the underlying sea water $\left(1.1 \times 10^{6} \mathrm{ml}^{-1}\right.$; see Fig. $\left.6 \mathrm{~A}\right)$. With the exception of the first sampling date, the greatest proportion of viruses were found to be in the $50-70 \mathrm{~nm}$ size class (Fig. 2). There was a decrease in the proportion of viruses in the $<50 \mathrm{~nm}$ size class and an increase in the proportion of viruses in the $50-70 \mathrm{~nm}$ size class throughout the bloom.

Bacterial abundances ranged from $6.1 \times 10^{9}$ bacteria $\mathrm{m}^{-2}\left(1.5 \times 10^{5} \mathrm{ml}^{-1}\right)$ to $4.15 \times 10^{11} \mathrm{~m}^{-2}\left(1.0 \times 10^{7} \mathrm{ml}^{-1}\right)$, counts which are similar to those of Smith et al. (1989). One bacterial slide per sample was enumerated since the error associated with the counts has previously been established as being less than 10\% (Kirchman et al. 1985). The increase in bacterial abundance over time is correlated with increasing concentrations of chlorophyll a (Fig. 1).

The virus-to-bacteria ratio (VBR) of 72 is among the highest ever reported in the literature (Fig. 3). The VBR tended to decrease from early to late spring as viral and bacterial abundances and bacterial community production increased (Figs. 1, 3 \& 4). The VBR was relatively constant on the first 3 sampling dates, suggesting that viral and bacterial production were occurring at a similar rate. However, later in the spring, the rate of increase of the bacteria was much greater than that of viruses.

Cell-specific thymidine assimilation rates ranged from $0.17 \times 10^{-21}$ to $4.03 \times 10^{-21} \mathrm{~mol} \mathrm{cell}^{-1} \mathrm{~h}^{-1}$ and gen-

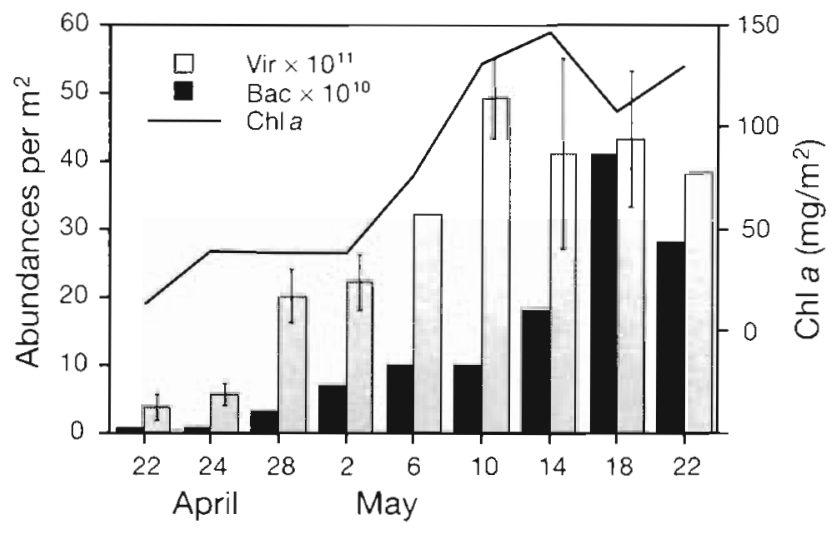

Fig. 1. Bacterial and viral abundances and chlorophyll concentration in the bottom $4 \mathrm{~cm}$ of Arctic sea ice samples collected near Resolute (N.W.T., Canada) during the 1992 spring bloom of ice algae. Chlorophyll values courtesy of Levasseur et al. (in press)

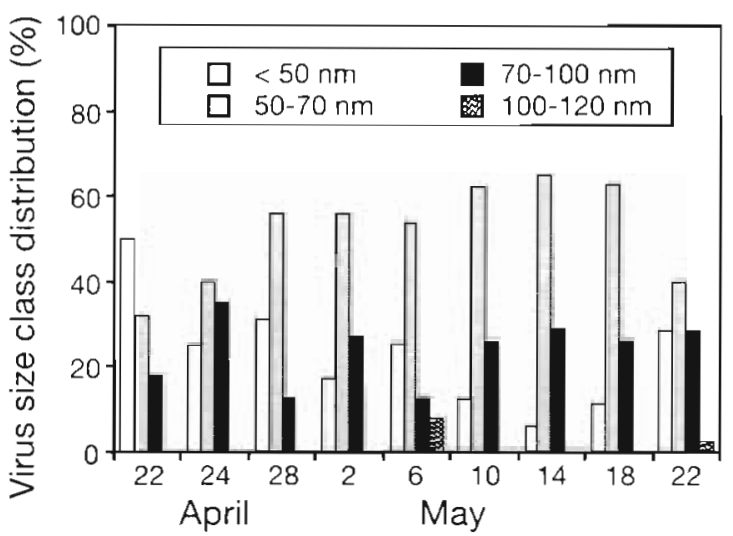

Fig. 2. Size distribution of viral capsid diameter, represented as a percentage of the total viral population, in the bottom $4 \mathrm{~cm}$ of sea ice during the 1992 spring bloom

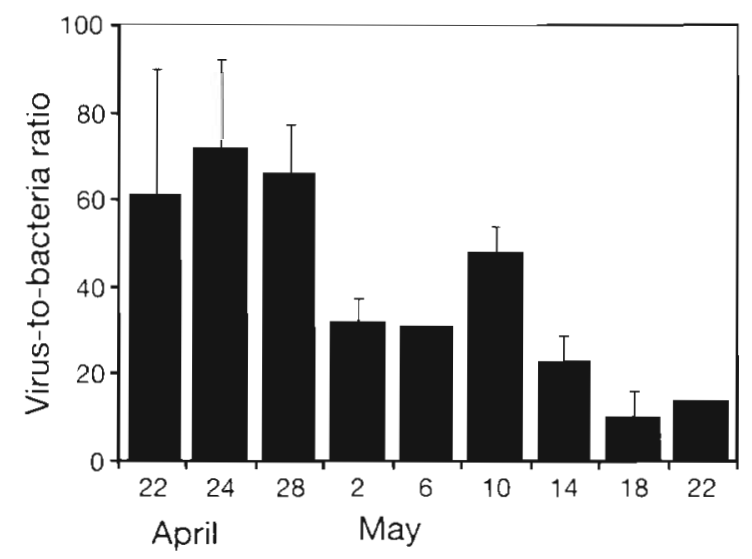

Fig. 3. Virus-to-bacteria ratio in sea ice during the study period 


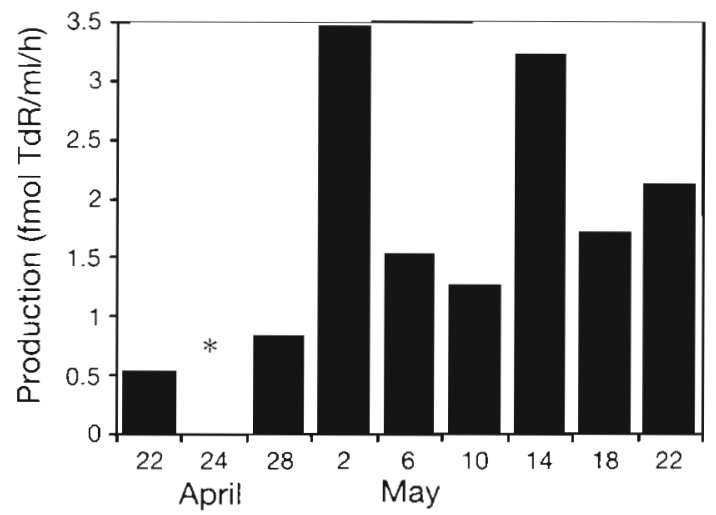

Fig. 4. Total bacterial community thymidine assimilation rates in sea ice during the spring bloom. *Assimilation rates not available

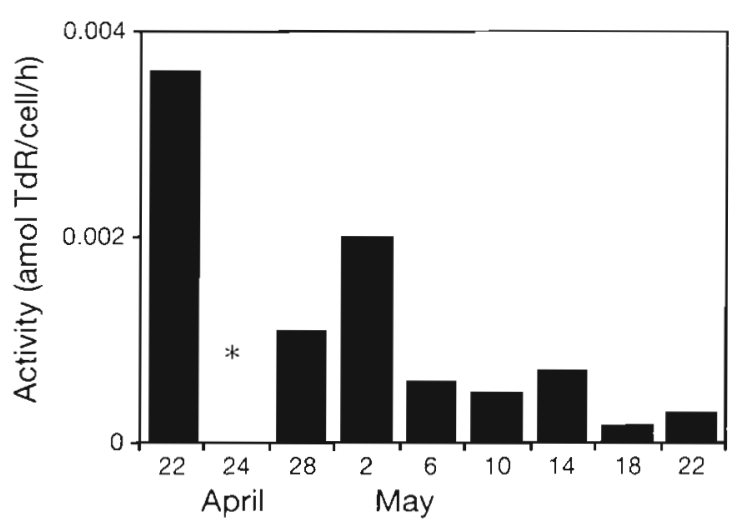

Fig. 5. Individual thymidine assimilation rates per bacterial cell in sea ice collected during the sampling period. *Assimilation rates per cell not available

erally decreased over the spring (Fig. 5). The value of $0.17 \times 10^{-21} \mathrm{~mol} \mathrm{~h}^{-1}$ is lower than what has previously been observed (Smith \& Clement 1990). On the other hand, total community assimilation of thymidine generally increased with bacterial abundance, with peaks of activity occurring on May 2 and 14 (Fig, 4)

In the profile of the ice core, bacterial and viral abundances were highest in the middle layer of the core, $0.5 \mathrm{~cm}$ from the ice-water interface to $1.5 \mathrm{~cm}$ into the ice (Fig. 6A). The VBR was also highest in this layer (Fig. 6B). Abundances were significantly higher in the ice than in the underlying sea water, however there was no obvious difference in the VBR between the ice and the underlying sea water (Fig. 6A, B). Bacterial activity was also highest in the middle layer of the ice core and tended to be more elevated in the ice than the underlying water (Fig. 7A). Cell-specific thymidine assimilation rates were considerably lower in the ice than the underlying column (Fig $7 \mathrm{~B}$ ).
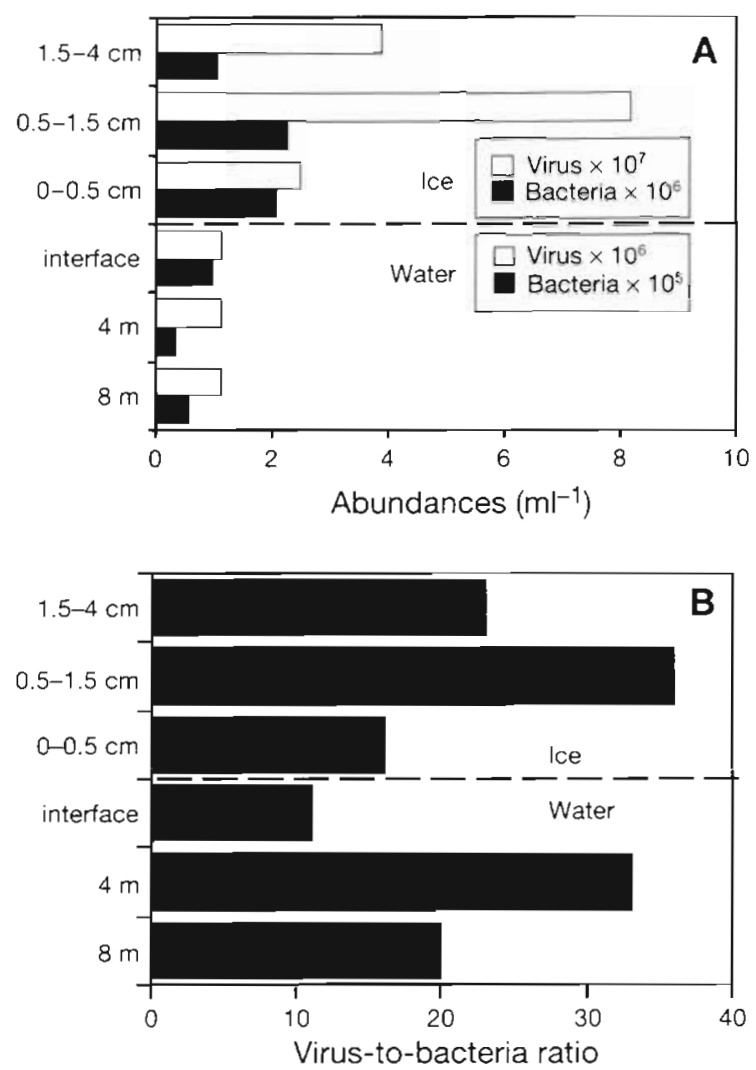

Fig. 6. (A) A vertical profile of bacterial and viral abundances in sea ice and the underlying water column in samples on May 7, 1992, near Resolute. (B) A vertical profile of the virusto-bacteria ratio in the ice and underlying water column

\section{DISCUSSION}

Our results provide the first account of viruses as a dynamic component of the microbial community in annual sea ice. Both bacterial and viral abundances increased with increasing bacterial activity. The rate at which viral abundance increased in proportion to bacterial abundance was much lower, as demonstrated by the reduced VBR later in the spring. There are several possible explanations for this observation, which may provide some insight into factors which control viral abundance in this milieu.

One is that aquatic viruses are largely speciesspecific (Sherman \& Brown 1978). The lower VBR observed in the late spring could then be due to the proliferation of bacteria which are resistant to phage infection. Hence viruses could have a greater impact on bacterial species composition than on the concentration of bacteria (Bratbak et al. 1992). A change in bacterial species composition may be inferred from changes in the viral community since viruses are 

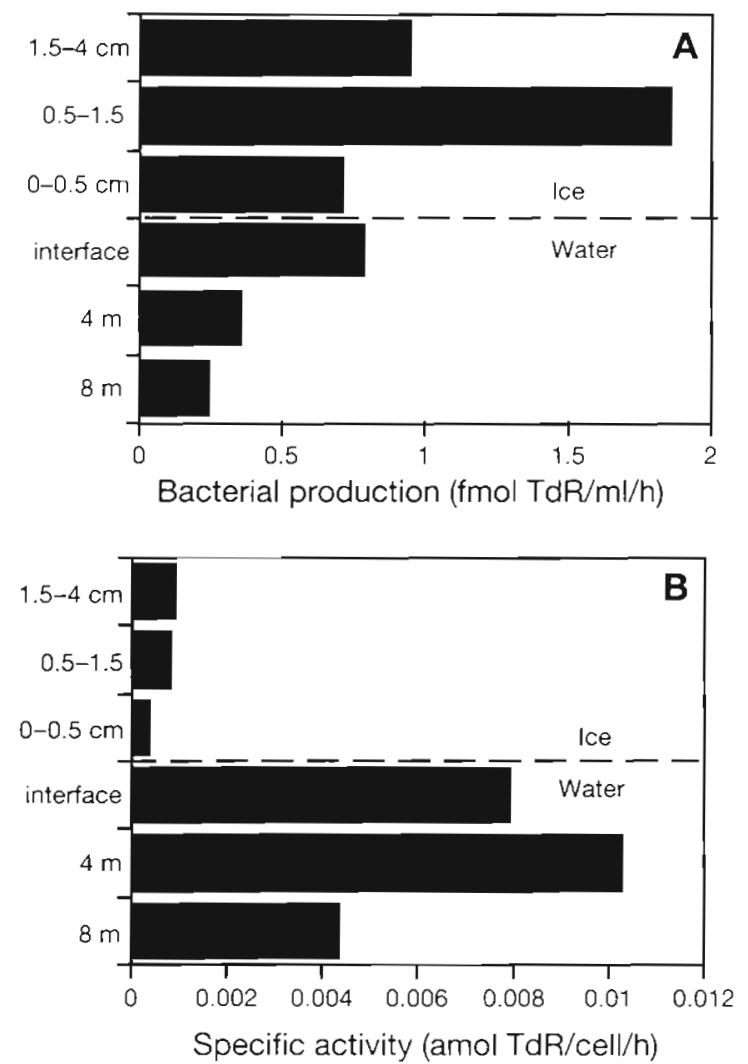

Fig. 7. (A) A vertical profile of total bacterial community thymidine assimilation rates in the ice and the underlying water column on May 7, 1992, near Resolute. (B) A vertical profile of individual thymidine assimilation rates per bacterial cell in the ice and underlying water column

species-specific and a product of the bacterial community itself. A slight shift in the virus particle size distribution over the course of the sampling period was abserved (Fig. 2): the viral community was initially dominated by particles of the $<50 \mathrm{~nm}$ size range which were then replaced by particles of the 50-70 nm size class. However, this inference must remain tentative until species dynamics and interactions in natural assemblages are better understood, since 2 or more different viral species could infect the same bacterial species. 'Immunity' to viral attack could also be conferred by the appearance of temperate phage infections. Once viral DNA is incorporated into the host genome, the bacterium is no longer susceptible to lytic infection by the same species of virus (Joklik et al. 1980).

Another explanation for the decreasing VBR is that high phage virulence and the increased viral population are associated with higher levels of productivity per bacterial cell. Our data suggest that viruses proliferated at a faster rate when cell-specifio thymidine assimilation rates were highest. One reason may simply be that the bacterial community at the beginning of the bloom had shorter generation times than at the end of the bloom. Thus virus particles would be formed and released at a higher rate when bacteria are doubling faster (Kokjohn et al. 1991). Another possibility is that an increase in individual bacterial activity due to favourable environmental conditions causes the more active bacteria to be more vulnerable to viral lytic attack or to increase their burst size. It is known that under ideal growth conditions there is a reduction in the production of the phage repressor protein such that the lytic pathway is favoured over lysogeny (Watson et al. 1987). However, viral infection of metabolically inactive cells would likely favour lysogenic growth and could also affect the VBR by acting as a sink for viruses.

A third, more speculative explanation for the temporal disequilibrium between phage and bacterial abundance is that heavy viral attack on the bacterial community early in the bloom period may have selected phage-resistant variants that were physiologically less efficient. Attachment sites for bacteriophage include membrane-bound receptors that are important to the bacteria. Bacteria with no or altered receptors are phage resistant but may have decreased nutrient transport capacity (Joklik et al. 1980). This interpretation thus accounts for the decrease in bacterial cellspecific thymidine incorporation rates and reduced viral proliferation purely on the basis of bacterialphage interactions.

Changes in the abundance of any organism are controlled by both production and loss mechanisms. All of the above explanations for the decreasing VBR assume that the rate of viral loss due to grazing or through physical factors remained constant throughout the observation period. It is possible that there could be variations in the loss rates of viruses from sea ice. Fluctuations in viral abundances in other aquatic systems indicate that loss may be rapid. These mechanisms are poorly understood and no attempt was made in this study to measure the loss of viral particles to grazers (González \& Suttle 1993) or to the underlying sea water. These are important issues to address in future research on microbial assemblages in sea ice.

It may be mistaken to claim that all the viruses observed were indeed bacteriophage. There are no methods currently available to distinguish between algal and bacterial viruses in natural assemblages. Viral microbial ecologists presently depend on capsid diameter or whether the particle is tailed or non-tailed. Van Etten et al. (1991) identified and reported the capsid diameter of several algal viruses, the majority of which were greater than $120 \mathrm{~nm}$, although $28 \%$ of the total number identified were less than $60 \mathrm{~nm}$ (Cochlan 
et al. 1993). Cochlan et al, (1993) also reported that the average capsid diameter for several cultured bacteriophage was $70 \mathrm{~nm}$ (Ackerman \& Dubow 1987b). According to these interpretations and our size class distribution values (Fig. 2), the majority of the particles we observed were likely bacteriophage. This claim is also supported by the notion that the dominant algal species in Arctic sea ice is the pennate diatom Nitzschia frigida (Levasseur et al. in press). No virus has been found to infect any member of the diatom class, the Bacillariophyceae (Van Etten et al. 1991). On the other hand, a marked decrease in diatom abundance has been observed when concentrated particles in the 0.002-0.2 $\mathrm{um}$ size range from sea water are added to batch cultures (Suttle et al. 1990). Bratbak et al. (1990) also observed a peak of viruses after the collapse of a diatom bloom. This peak in viruses coincided with a dense bacterial colonization of the dead or senescent algal cells. Again it is unclear whether the viruses were a product of the diatoms or of the increased activity of the bacterial population.

Distinguishing between bacterial and algal viruses on the basis of whether they are tailed or non-tailed is very uncertain, since several known bacteriophages are non-tailed (Joklik et al. 1980). Virus tails are subject to damage when fixed with glutaraldahyde or formaldehyde and stored for variable periods of time. Brownian motion of viruses may cause collisions resulting in breakage. This may result in inaccurate estimations of the abundance of tailed particles observed in natural samples, particularly in older samples. Cultured phage used in microbial genetic experiments are often preserved in gelatin to soften collision (Silhavy et al. 1984). New methods of preserving virus samples may be very important if samples are going to be stored for extended periods and if the percentage of tailed particles is an important consideration.

The fact that both bacteria and virus concentrations were highest slightly away $(0.5$ to $1.5 \mathrm{~cm})$ from the icewater interface (Fig. 6A) may be the result of the interaction of both physical and biological forces. Bacteria and viruses or flocculent material containing these organisms may be physically removed from the ice via turbulence at the ice-water interface. Resuspension losses would be reduced further into the ice. The bacterial community in the intermediate layer was also more active (Fig. 7A), which may encourage viral activity or be a result of it. Cell-specific growth rates within the ice were much lower than those observed in the water column (Fig. 7B) suggesting that inactive cells were accumulating within the ice

This study demonstrates that viruses are a dynamic component of sea ice microbial communities. Furthermore, on the basis of the elevated VBRs seen at
Resolute, viral proliferation and accumulation appear to be favoured in sea ice relative to oper water. The identity of the host organisms, algal or bacterial, is an important element of ice viral ecology that has yet to be addressed.

Acknowledgements. We thank Gilles Clotteau for the collection of samples at Resolute and we are very grateful to $\mathrm{Dr}$ Maurice Levasseur of the Ministry of Fisheries and Oceans Canada at the Institut Maurice-Lamontagne and Dr Michel Gosselin of the Département d'Océanographie, Université du Québec à Rimouski, for the use of their chlorophyll data taken in collaboration during the Canada-Japan Saroma-Ko Lagoon-Resolute Passage Study (SARES project). We thank G. S. Moeck, who provided us with T5 phage, and his useful comments along with the comments of 3 anonymous reviewers who helped improve the manuscript considerably. This research was funded by the Université du Québec à Montréal (S.K.J), a UQAM student scholarship (R.M.), the Canadian Department of External Affairs (S.K.J.), NSERC Canada (D.F.B.), and a FCAR-Québec team grant to D.F.B., S.K.J, $D$. Planas and $Y T$ Prairie. Logislic support for field work was provided by the Canadian Polar Continental Shelf Project. This is a contribution from SARES and le Groupe de Recherche en Limnologie (GRIL)

\section{LITERATURE CITED}

Ackerman, H. W., Dubow, M. S. (1987a). Viruses of prokaryotes, Vol. 1. General properties of bacteriophages. CRC Press, Boca Raton

Ackerman, H. W., Dubow, M. S. (1987b). Viruses of prokaryotes, Vol. 2. Natural groups of bacteriophages. CRC Press. Boca Raton

Bergh, Ø., Børsheim, K. Y., Bratvak, G., Heldal, M. (1989) High abundances of viruses found in aquatic environments. Nature 340: 467-468

Bratbak, G., Heldal, M., Norland, S., Thingstad, T F. (1990) Viruses as partners in spring bloom trophodynamics Appl. environ. Microbiol. 56: 1400-1405

Bratbak, G., Heldal, M., Thingstad, T. F., Riemann, B. Haslund, O. H. (1992). Incorporation of viruses into the budget of microbial C-transfer. A first approach. Mar. Ecol. Prog. Ser. 83: 273-280

Cochlan, W. P., Wikner, J., Stewart, G. F., Smith, D. C., Azam, F. (1993). Spatial distribution of viruses, bacteria and chlorophyll $a$ in neritic, oceanic and estuarine environments. Mar. Ecol. Prog. Ser. 82: 151-162

Fuhrman, J. (1992). Bacterioplankton roles in cycling of organic matter: the microbial food web. In: Falkowski, G. P., Woodhead, A. D. (eds.) Primary productivity and biogeochemical cycling in the sea. Plenum Press, New York, p. 361-383

Fuhrman, J. A., Azam, F. (1982). Thymidine incorporation as a measure of heterotrophic bacterioplankton production in marine surface waters: evaluation and fielc results. Mar. Biol. 66: 109-110

González, J. M., Suttle, C. A. (1993). Grazing by marine nanoflagellates on viruses and virus-sized particles: ingestion and digestion. Mar. Ecol. Prog. Ser. 94: 1-10

Grossi, S. M., Kottmeier, S., Sullivan, C. W. (1984). Sea ice microbial communities. III. Seasonal abundance of microalgae and associated bacteria. McMurdo Sound, Antarctica. Microbiol. Ecol. 10: 231-242 
Hammond, G. W., Hazelton, P. R., Chang, I., Klisko, B. (1981). Improved detection of viruses by electron microscopy after direct ultracentrifuge preparation of specimens. J. clin. Microbiol, 14: 210-221

Heldal, M., Bratbak, G. (1991). Production and decay of viruses in aquatic environments. Mar. Ecol. Prog. Ser. 72: 205-212

Horner, R. A. (1989). Arctic sea-ice biota. In: Hermann, Y (ed.) The Arctic seas; climatology, oceanography, geology, and biology. Van Nostrand Reinhold Co., New York, p. $123-146$

Joklik, W. G., Willet, H. P., Amos, D. B. (1980). Zinsser microbiology, 17 th edn. Appleton-Century-Croft, New York

Kirchman, D., K'Nees, E., Hodson, R. (1985). Leucine incorporation and its potential as a measure of protein synthesis by bacteria in natural aquatic systems. Appl. environ. Microbiol. 49: 599-607

Klut, M. E., Stockner, J. G. (1990). Virus-like particles in an ultra-oligotrophic lake on Vancouver Island, British Columbia. Can. J. Fish. Aquat. Sci. 47: 725-730

Kokjohn, T. A., Sayler, G. S., Miller, R.V. (1991). Attachment and replication of Pseudomonas aeruginosa bacteriophages under conditions similating aquatic environments. J. gen. Microbiol. 137: 661-666

Kottmeier, S. T., Grossi, S. M., Sullivan, C. W. (1987). Sea ice microbial communities. VIII. Bacterial production in annual sea ice of McMurdo Sound, Antarctica. Mar. Ecol. Prog. Ser. 35: 175-186

Levasseur, M., Gosselin, M., Michaud, S. (1994). A new source of dimethylsulphide (DMS) for the Arctic atmosphere: ice diatoms. Mar. Biol. (in press)

Paul, J H., Frischer, M. E., Thurmond, J M. (1991). Gene transfer in marine water column and sediment microcosms by natural plasmid transformation. Appl. environ. Microbiol. 57: 1509-1515

This article was submitted to the editor
Porter, K. G., Feig, Y S. (1980). The use of DAPI for identufying and counting aquatic microflora. Limnol. Oceanogr. 25: 943-948

Proctor, L. M., Fuhrman, J. A. (1990). Viral mortality of marine bacteria and cyanobacteria. Nature 343: 60-62

Proctor, L. M., Fuhrman, J. A. (1991). Roles of viral infection in organic particle flux. Mar. Ecol. Prog. Ser. 69: 133-142

Sherman, L. A., Brown, R. M. (1978). Cyanophages and viruses of eukaryotic algae. In: Fraenkel-Conrat, H. (ed.) Comprehensive virology, Vol. 12. Plenum Press, New York, p. 145-234

Silhavy, T J., Berman, M. L., Inquist, L. W. (1984). Experiments with gene fusions. Cold Spring Harbour Press, Cold Spring Harbour

Smith, R. E. H., Clement, P. (1990). Heterotrophic activity and bacterial productivity assemblages of microbes from sea jce in the high Arctic. Polar Biol. 10: 351-357

Smith, R. E. H., Clement, P., Cota, G. F. (1989). Population dynamics of bacteria in Arctic sea ice. Microbiol. Ecol. 17: $63-76$

Suttle, C. A. (1993) Enumeration and isolation of marine viruses. In: Kemp, P. F., Sherr, B. F., Sherr, E. B., Cole, J. J. (eds.) Handbook of methods in aquatic microbial ecology. Lewis Publishers, Boca Raton, p. 121-134

Suttle, C. A., Chang, A. M., Cottrell, M. T (1990). Infection of phytoplankton by viruses and reduction of primary productivity. Nature 347: 467-469

Watson, J. D., Hopkins, N. H., Roberts, J. W., Steitz, J A., Weiner, A. (1987). Molecular biology of the gene, 4th edn. The Benjamin/Cummins Publishing Company, Menlo Park

Van Etten, J. L., Lane, L. C., Meints, R. H. (1981). Virus and virus-like particles of eukaryotic algae. Microbiol. Rev. 55: $568-620$

Manuscript first received: November 18, 1993

Revised version accepted: May 9, 1994 